\title{
PREVALENCE OF GALLSTONES AMONG PREGNANT WOMEN IN A SOUTH INDIAN DISTRICT
}

\author{
Sathiyamoorthy Jothy
}

1Faculty, Department of Radiology, Government Theni Medical College and Hospital, Theni, Tamilnadu, India.

\section{ABSTRACT}

\section{BACKGROUND}

Gallstone disease is more common in women than men. Pregnancy is a known risk factor for developing gallstones. ${ }^{1}$ We wanted to assess the prevalence of biliary sludge and gallstone disease during pregnancy.

\section{METHODS}

The study was done on 600 pregnant women from community with gestational age upto 25 weeks. It is a retrospective study. Ultrasound images and reports were reviewed.

\section{RESULTS}

The prevalence of biliary sludge and gallstones during pregnancy was found to be $1.3 \%$ and $2.7 \%$ respectively.

\section{CONCLUSIONS}

The prevalence of either biliary sludge or gallstone among pregnant women with gestational age of upto 25 weeks was $4 \%$. The prevalence of gallstone disease increased with increased parity.

HOW TO CITE THIS ARTICLE: Jothy S. Prevalence of gallstones among pregnant women in a South Indian district. J. Evolution Med. Dent. Sci. 2019;8(18):1459-1462, DOI: 10.14260/jemds/2019/325

\section{BACKGROUND}

Gallstone disease is more common in women than men. Pregnancy is a known risk factor for developing gallstones. ${ }^{1}$ Both the frequency and number of pregnancies are major risk factors for cholesterol gallstones. ${ }^{2-7}$ New biliary sludge (A precursor to gallstones) and gallstones may form in pregnant women. ${ }^{8-11}$ Gallstones are easily detected with ultrasound. Pregnant women routinely undergo obstetric ultrasound. This study was carried out to find prevalence of gallstone in pregnant women by additional upper abdominal ultrasound screening during routine antenatal ultrasound.

\section{METHODS}

Ultrasonography of abdomen and pelvis was performed with Hitachi Aloka Arietta S60 (Tokyo, Japan) machine with 1-5 $\mathrm{MHz}$ convex probe, 3-7 $\mathrm{MHz}$ linear probe and 2-10 $\mathrm{MHz}$ Transvaginal probe. 1-5 $\mathrm{MHz}$ convex probe was used for screening of gall bladder. Single radiologist with over 12 years of experience in ultrasound performed all the ultrasound examinations.

\section{Study Sample}

600 consecutive pregnant women with gestational age upto 25 weeks (Gestational age as per biometry) who were referred for routine obstetric ultrasound between November 2018 to March 2019 at Vishnupriyadharshini scans, Theni. It is a retrospective study. Ultrasonography referral forms, ultrasound images and ultrasound reports were assessed retrospectively. If a pregnant woman had come for more than one ultrasound within the study period, she was counted as single patient.

'Financial or Other Competing Interest': None.

Submission 28-03-2019, Peer Review 23-04-2019,

Acceptance 25-04-2019, Published 06-05-2019.

Corresponding Author:

Dr. Sathiyamoorthy Jothy,

163/161, Subban Street,

Theni-625531, Tamilnadu, India.

E-mail: drsathiyamoorthy@gmail.com

DOI: $10.14260 /$ jemds $/ 2019 / 325$

\section{(c) (i) $(9)$}

\section{Definition of Terms}

Biliary sludge is defined as echogenic mobile debris layering dependently in the gallbladder without posterior acoustic shadowing. Microlithiasis is defined as small calculi that are less than $3 \mathrm{~mm}$ in size. In this study we included microlithiasis in the biliary sludge category. Gallstones are echogenic material (High amplitude echoes) that measure 3 $\mathrm{mm}$ or more; gallstones usually cast acoustic shadowing Small stones (Less than $5 \mathrm{~mm}$ ) may not cast acoustic shadowing1 but will still appear echogenic; mobility differentiates gallstones from polyps. ${ }^{1}$ Examples of biliary sludge, microlithiasis and gallstones are demonstrated in the following figures (Figure 1a, Figure 1b and Figure 2) from our study sample.

\section{Statistical Analysis}

- Among 600 pregnant women, 24 were found to have either gallstone or biliary sludge.

- Sample size (Number of pregnant women) $=600$

- Number of positive (Pregnant women with either gallstone or sludge) $=24$

- Confidence interval: $95 \%$

- Confidence interval method: Clopper-Pearson exact (Binomial proportion confidence interval)

- Proportion/ prevalence $=0.0400(4.0 \%)$

- Lower $95 \%$ confidence limit is $0.0258(2.6 \%)$

- Upper 95\% confidence limit is 0.0589 (5.9\%)

- Proportion of pregnant women with either gallstone or biliary sludge is $4.0 \%, 95 \%$ confidence interval $=2.6 \%$ to $5.9 \%$

- Proportion of primigravida with either gallstone or biliary sludge is $3.4 \%, 95 \%$ confidence interval $=1.7 \%$ to $6.0 \%$

- Proportion of multigravida with either gallstone or biliary sludge is $4.7 \%, 95 \%$ confidence interval $=2.5 \%$ to $7.9 \%$ 


\section{RESULTS}

There were 600 pregnant women with gestational age upto 25 weeks. Among the 131 women in first trimester, there were 7 cases of ectopic gestations and one with molar pregnancy. Among the 469 women with gestational age of 13 weeks and above, there were 3 women with intrauterine fetal death.

\begin{tabular}{|c|c|c|c|c|}
\hline $\begin{array}{c}\text { Maternal } \\
\text { Age in } \\
\text { Years }\end{array}$ & $\begin{array}{c}\text { Number of } \\
\text { all Pregnant } \\
\text { Women } \\
\text { (without or } \\
\text { with } \\
\text { Gallstone or } \\
\text { Sludge) }\end{array}$ & $\begin{array}{c}\text { Number of } \\
\text { Pregnant } \\
\text { Women } \\
\text { with } \\
\text { Gallstone }\end{array}$ & $\begin{array}{c}\text { Number of } \\
\text { Pregnant } \\
\text { Women } \\
\text { with } \\
\text { Biliary } \\
\text { Sludge }\end{array}$ & $\begin{array}{c}\text { Number of } \\
\text { Pregnant } \\
\text { Women } \\
\text { with either } \\
\text { Gallstone } \\
\text { or Sludge }\end{array}$ \\
\hline $18-20$ & 106 & 0 & 0 & 0 \\
\hline $21-25$ & 268 & 9 & 6 & 15 \\
\hline $26-30$ & 159 & 6 & 1 & 7 \\
\hline $31-35$ & 56 & 1 & 1 & 2 \\
\hline $36-40$ & 10 & 0 & 0 & 0 \\
\hline $41-45$ & 1 & 0 & 0 & 0 \\
\hline Total & 600 & 16 & 8 & 24 \\
\hline \multicolumn{5}{|c|}{ Table 1. Age Distribution } \\
\hline \multicolumn{5}{|c|}{} \\
\hline
\end{tabular}

\begin{tabular}{|c|c|c|c|c|}
\hline Gravida & $\begin{array}{c}\text { Number of } \\
\text { all Pregnant } \\
\text { Women } \\
\text { (with or } \\
\text { without } \\
\text { Gallstone) }\end{array}$ & $\begin{array}{c}\text { Number } \\
\text { of } \\
\text { oregnant } \\
\text { Women } \\
\text { with } \\
\text { Gallstone }\end{array}$ & $\begin{array}{c}\text { Number of } \\
\text { Pregnant } \\
\text { Women } \\
\text { with } \\
\text { Biliary } \\
\text { Sludge }\end{array}$ & $\begin{array}{c}\text { Number of } \\
\text { Pregnant } \\
\text { Women } \\
\text { with either } \\
\text { Gallstone } \\
\text { or Sludge }\end{array}$ \\
\hline Primigravida & 324 & 6 & 5 & 11 \\
\hline Multigravida & 276 & 10 & 3 & 13 \\
\hline Total & $\mathbf{6 0 0}$ & $\mathbf{1 6}$ & $\mathbf{8}$ & $\mathbf{2 4}$ \\
\hline \multicolumn{5}{|c|}{ Table $\mathbf{2}$} \\
\hline
\end{tabular}

\begin{tabular}{|c|c|c|c|c|}
\hline $\begin{array}{c}\text { Gestational } \\
\text { Age }\end{array}$ & $\begin{array}{c}\text { Number of } \\
\text { all } \\
\text { Pregnant } \\
\text { Women } \\
\text { (with or } \\
\text { without } \\
\text { Gallstone) }\end{array}$ & $\begin{array}{c}\text { Number of } \\
\text { Pregnant } \\
\text { Women } \\
\text { with } \\
\text { Gallstone }\end{array}$ & $\begin{array}{c}\text { Number } \\
\text { of } \\
\text { Pregnant } \\
\text { Women } \\
\text { with } \\
\text { Sludge }\end{array}$ & $\begin{array}{c}\text { Number of } \\
\text { Pregnant } \\
\text { Women } \\
\text { with } \\
\text { either } \\
\text { Gallstone } \\
\text { or Sludge }\end{array}$ \\
\hline$\leq 12$ weeks & 131 & 3 & 2 & 5 \\
\hline $13-25$ weeks & 469 & 13 & 6 & 19 \\
\hline \multicolumn{5}{|c|}{ Table 3 } \\
\hline
\end{tabular}

\begin{tabular}{|c|c|c|c|c|}
\hline $\begin{array}{c}\text { Type of } \\
\text { Pregnancy }\end{array}$ & $\begin{array}{c}\text { Number of } \\
\text { all } \\
\text { Pregnant } \\
\text { Women } \\
\text { (with or } \\
\text { without } \\
\text { Gallstone) }\end{array}$ & $\begin{array}{c}\text { Number of } \\
\text { Pregnant } \\
\text { Women } \\
\text { with } \\
\text { Gallstone }\end{array}$ & $\begin{array}{c}\text { Number of } \\
\text { Pregnant } \\
\text { Women } \\
\text { with } \\
\text { Biliary } \\
\text { Sludge }\end{array}$ & $\begin{array}{c}\text { Number of } \\
\text { Pregnant } \\
\text { Women } \\
\text { with } \\
\text { either } \\
\text { Gallstone } \\
\text { or Sludge }\end{array}$ \\
\hline Singleton & 578 & 15 & 8 & 23 \\
\hline $\begin{array}{c}\text { Twin } \\
\text { pregnancy }\end{array}$ & 11 & 1 & 0 & 1 \\
\hline \multicolumn{5}{|c|}{ Table 4 } \\
\hline
\end{tabular}

\begin{tabular}{|c|c|}
\hline $\begin{array}{c}\text { Chronic calcific } \\
\text { pancreatitis }\end{array}$ & 2 \\
\hline Portal cavernoma & 1 \\
\hline Table 5. Incidentally Detected other Hepatobiliary/ \\
Pancreatic Diseases in These Pregnant Women during \\
Upper Abdominal Ultrasound Screening \\
\hline
\end{tabular}

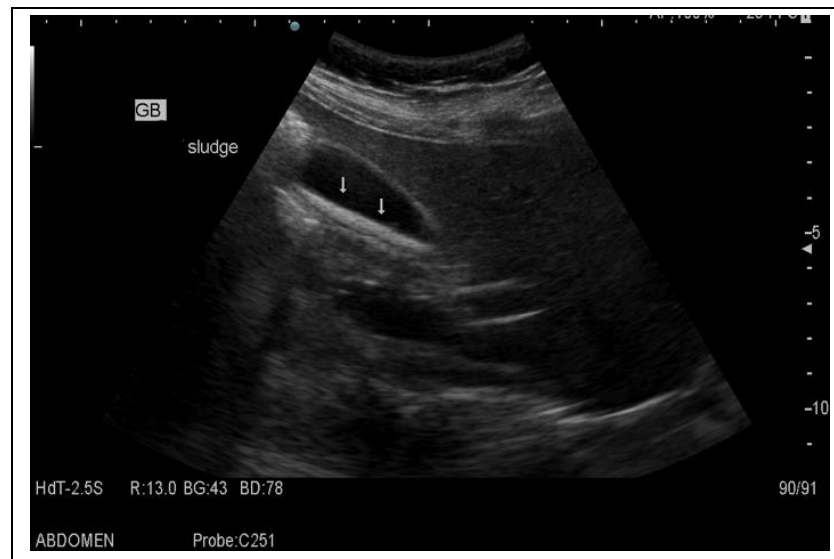

Figure 1a. Showing Biliary Sludge as Layering Echogenic Material in Gallbladder without Shadowing

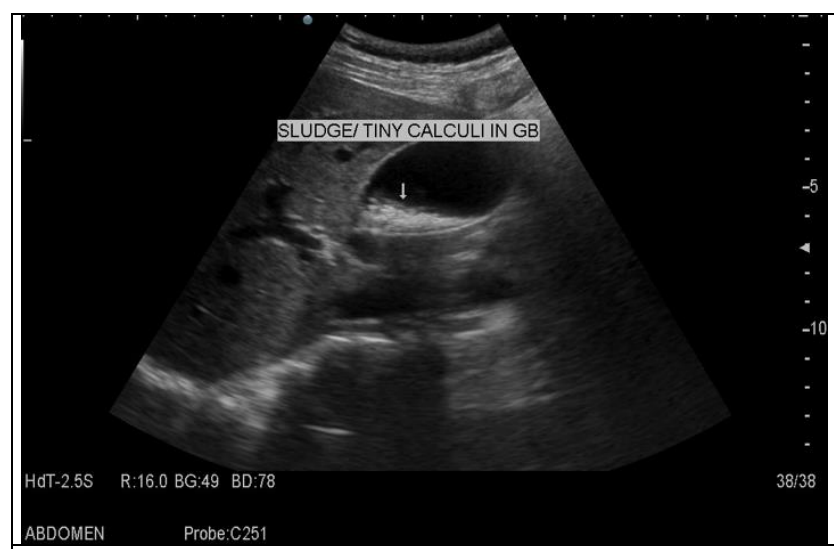

Figure 1b. Showing Biliary Sludge/Microlithiasis (Same Patient as in Figure 1a, but After 10 Weeks). We can Appreciate Faint Shadowing in Figure 1b. Sludge has Become Microlithiasis in 10 Weeks' Time

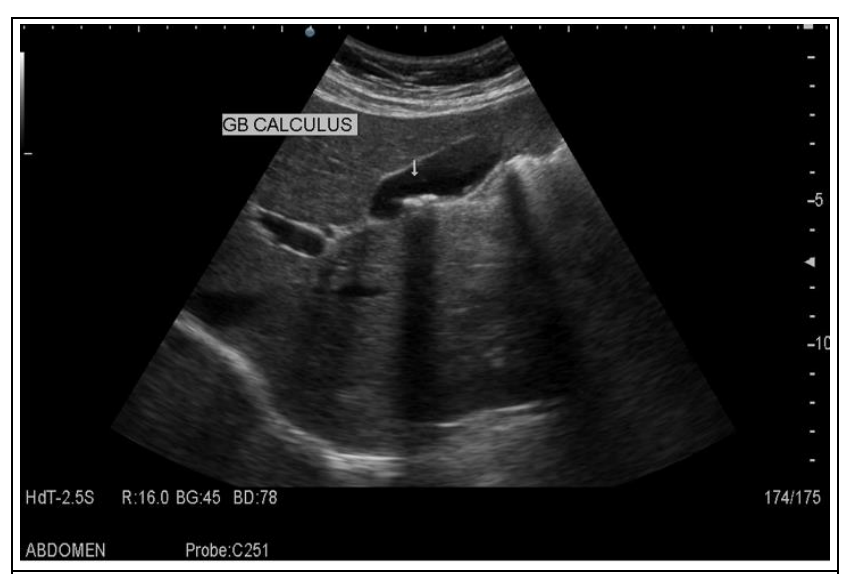

Figure 2. Showing Cholelithiasis. Two Calculi in The Lumen of Gallbladder with Posterior Acoustic Shadowing

Note

Calcific foci in liver (Suggesting healed infections) and haemangiomas in liver are not uncommon; these cases are not included in the incidentally detected findings. Renal calculi are prevalent in our region and so we do not include renal calculi in the incidentally detected findings. 


\section{Inclusion Criteria}

Pregnant women (Belonging to any age group and any parity) with gestational age upto 25 weeks (Gestational age as per biometry). Screening ultrasound of upper abdomen was not performed in pregnant women with gestational age of 26 weeks and above and so they were not included in the study. Twin pregnancies were also included in the study sample. Ectopic gestations and intrauterine fetal deaths were also included in the study sample.

\section{Exclusion Criteria}

History of cholecystectomy. During the study period, there was mention of history of cholecystectomy in ultrasound reports of two pregnant women, who were excluded. Those with missed abortion or complete abortions (During study period) were not included in the study.

\section{DISCUSSION}

During pregnancy oestrogen and progesterone levels increase. Increased oestrogen increases biliary secretion of cholesterol and decreases secretion of bile salts. Increased progesterone causes gallbladder stasis. Together these mechanisms predispose to gallstone formation. 9,12

In our study we found 24 (4\%) cases of gallstones/ biliary sludge (either gallstones or biliary sludge) in 600 pregnant women with gestational age upto 25 weeks. There were 16 cases $(2.7 \%)$ of gallstones and 8 cases $(1.3 \%)$ of biliary sludge.

Among 324 primigravida, 11 (3.4\% of primigravida, 1 in 29 primigravida) had gallstones/ biliary sludge (either gallstones or biliary sludge). Among 276 multigravidas, 13 (5\% of multigravida, 1 in 21 multigravida) had gallstones/ biliary sludge. The prevalence of gallstones/ biliary sludge is more among multigravida than primigravida.

Among 131 women with first trimester pregnancy, 5 (3.8\%) had gallstones/ biliary sludge. Among 469 women with gestational age between 13-25 weeks, 19 (4.0\%) had gallstones/ biliary sludge.

106 women were 18-20 years old of which none had gallstones/ biliary sludge. 427 women were 21-30 years old of which 22 (5.1\%) had gallstones/ biliary sludge. 61 women were 31 years or older of which two (3.3\%) had gallstones/ biliary sludge.

578 pregnant women had single live intrauterine pregnancy. Among them, 23 had gallstone/ biliary sludge (4\%). 11 pregnant women had twin pregnancy among which one had gallstone $(9 \%)$.

In a previous study done by Richa Gangwar et al, the incidence of biliary sludge and gallbladder stones during pregnancy was found to be $14.4 \%$ and $6.67 \%$ respectively 11 . In our study prevalence of sludge and gallstone is $1.3 \%$ and $2.7 \%$ respectively. The cause for lesser prevalence in our study could not be explained. One possibility is that their study population was north Indian pregnant women while ours is south Indian pregnant women. South Indians generally have lesser BMI compared to north Indians. ${ }^{13}$ Ethnic difference could be one among the causes for reduced prevalence of gallstone in our study population.

In another previous study done in south India by Anita Chandrakumar et $\mathrm{al}^{14}$ the incidence of gallstone in pregnant women was $1 \%$. In our study the prevalence of gallstone in pregnant women (With gestation age upto 25 weeks) was $2.7 \%$.

We found two cases of chronic calcific pancreatitis among these 600 pregnant women. Neither of these two had gallstones or sludge. Both of them had diabetes, and prior to ultrasound they were considered to have gestational diabetes. After ultrasound, the diagnosis was changed to type 1 diabetes and both of them are on insulin at time of writing of this article. Detection of chronic calcific pancreatitis on upper abdominal screening in pregnant women is beneficial for appropriate management of patients.

\section{Limitations}

1. We did not study the incidence of gallstone during pregnancy. We studied the prevalence only. To study incidence, we have to do prospective study, enrolling patients, and follow them up to find, how many among the pregnant women (Who have no gallstone or sludge in first study at time of enrolment) subsequently develop 'new' stone or sludge during course of pregnancy.

2. We had not performed screening of upper abdomen in all pregnant women. We confined our study to pregnant women with gestational age upto 25 weeks. This is a major limitation as sludge formation begins in the first trimester and increases up to 4 to 6 weeks postpartum ${ }^{15}$. Study done by Richa Gangwar et al also shows increased incidence of biliary sludge and gallstones in third trimester of pregnancy. So, it is possible that our study underestimates the total prevalence of gallstones in pregnant women as it does not address prevalence of gallstone in pregnant women in third trimester. Ultrasound follow-up of the patients with gallstones (Detected during pregnancy) in post-natal period will be useful to study natural history of the disease.

\section{CONCLUSIONS}

Prevalence of either gallstones or biliary sludge in pregnant women (with gestational age upto 25 weeks) is $4 \%$ in our region. Prevalence of gallstones increased with increasing parity.

\section{ACKNOWLEDGEMENTS}

I thank Prof. Dr. P. Thirumalai Kolundu Subramanian, M.D., for his encouragement and valuable inputs. I thank my professors, seniors and colleagues for providing reference articles and for their inputs in statistical analysis.

\section{REFERENCES}

[1] Khailili K, Wilson SR. The biliary tree and gallbladder. In: Rumack CM, Wilson SR, Charboneau JW, et al. eds. $3^{\text {rd }}$ edn. Diagnostic ultrasound. Missouri: Elsevier Mosby 2005;1:195.

[2] Everhart JE, Khare M, Hill M, et al. Prevalence and ethnic differences in gallbladder disease in the United States. Gastroenterology 1999;117(3):632-9.

[3] Thijs C, Knipschild P, Leffers P. Pregnancy and gallstone disease: an empiric demonstration of the importance of specification of risk periods. Am J Epidemiol 1991;134(2):186-95. 
[4] Friedman GD, Kannel WB, Dawber TR. The epidemiology of gallbladder disease: observations in the Framingham study. J Chronic Dis 1966;19(3):27392.

[5] Barbara L, Sama C, Morselli-Labate AM, et al. A population study on the prevalence of gallstone disease: the Sirmione study. Hepatology 1987;7(5):913-7.

[6] Rome Group for Epidemiology and Prevention of Cholelithiasis (GREPCO). The epidemiology of gallstone disease in Rome, Italy. Part II. Factors associated with the disease. Hepatology 1988;8(4):907-13.

[7] Stampfer MJ, Maclure KM, Colditz GA, et al. Risk of symptomatic gallstones in women with severe obesity. Am J Clin Nutr 1992;55(3):652-8.

[8] Maringhini A, Marceno MP, Lanzarone F, et al. Sludge and stones during pregnancy. J Hepatol 1987;5:21823.

[9] Maringhini A, Ciambra M, Baccelliere P, et al. Biliary sludge and gallstones in pregnancy: incidence, risk factors and natural history. Ann Intern Med 1993;119(2):116-20.
[10] Tsimoyiannis EC, Antoniou NC, Tsaboulas C, et al. Cholelithiasis during pregnancy and lactation. Prospective study. Eur J Surg 1994;160(11):627-31.

[11] Gangwar R, Dayal M, Dwivedi M, et al. Gallbladder disease in pregnancy. J Obstet Gynaecol India 2011;61(1):57-61.

[12] Etminan M, Delaney JA, Bressler B, et al. Oral contraceptives and the risk of gallbladder disease: a comparative safety study. CMAJ 2011;183(8):899-904.

[13] Mungreiphy NK, Dhall M, Tyagi R, et al. Ethnicity, obesity and health pattern among Indian population. J Nat Sci Biol Med 2012;3(1):52-9.

[14] Anita C, Kumar P, Malathi S, et al. Gallstones in pregnancy--a prevalence study from India. J Clin Gastroenterol 2008;42(9):1065-6.

[15] Ko CW, Beresford SAA, Schulte SJ, et al. Incidence, natural history and risk factors for biliary sludge and stones during pregnancy. Hepatology 2005;41(2):35965. 